\title{
Diet, alcohol, body mass, and social factors in relation to blood pressure: the Caerphilly Heart Study
}

\author{
PAUL ELLIOTT, ${ }^{1}$ ANN M FEHILY, ${ }^{2}$ PETER M SWEETNAM, ${ }^{2}$ AND JOHN W G \\ YARNELL ${ }^{2}$ \\ From the Medical Unit, ${ }^{1}$ St Mary's Hospital Medical School, Norfolk Place, London W2, the Department of \\ Epidemiology, ${ }^{1}$ London School of Hygiene and Tropical Medicine, Keppel Street, London WC1E 7HT, and the \\ MRC Epidemiology Unit, ${ }^{2} 4$ Richmond Road, Cardiff CF2 3AS, Wales
}

SUMMARY Data for 387 men who had completed seven-day weighed dietary records as part of the Caerphilly Heart Study were examined for relations of alcohol, diet, body mass index (BMI), and other variables to blood pressure. These included age, smoking, exercise, and social class. For men not on antihypertensive treatment $(n=356)$ regression analysis showed that age $(p<0.001)$, BMI $(\mathrm{p}<0.05)$, and alcohol intake $(\mathrm{p}<0.01)$ were significantly related to systolic blood pressure, and BMI $(\mathrm{p}<0.001)$ and alcohol intake $(\mathrm{p}<0.01)$ to diastolic blood pressure. In addition, protein intake $(\mathrm{p}<0.05)$ was significantly and inversely related to the risk of being hypertensive, but other dietary variables were not related to blood pressure. For men on antihypertensive treatment $(n=31)$ significant inverse correlations were observed between diastolic blood pressure and the intakes of potassium $(\mathrm{p}<0.01)$, fibre $(\mathrm{p}<0.001)$, polyunsaturated fat $(\mathrm{p}<0.01)$, and a number of other dietary variables. Reasons for these differences are discussed.

The risk of heart disease and stroke increases with blood pressure, even within the 'normal' range.' Against this background, primary prevention of hypertension by nutritional-hygienic means has been advocated, ${ }^{2}$ but the evidence is inconclusive. Relations to blood pressure have been described positively for salt $^{3}$ and alcohol; ${ }^{4-9}$ negatively for potassium, ${ }^{10} 11$ fibre, ${ }^{12}$ polyunsaturated rather than saturated fats, ${ }^{13}$ and vegetarianism; ${ }^{14}$ and both positively and negatively for calcium. ${ }^{15-18}$

Many of the studies relating diet to blood pressure have relied on dietary methodology (such as 24-hour recall) of questionable validity for within population comparisons. ${ }^{19}$ We believe that this is the first study to examine this question using the seven-day weighed dietary inventory method, which is considered the best method available for epidemiological surveys. ${ }^{19} \mathrm{We}$ were able to explore the independent effects of diet, alcohol, and obesity, and to take account of a number of variables potentially confounding the diet-blood pressure relation, including exercise, social class, and smoking.

\section{Methods}

The Caerphilly Heart Study is a longitudinal study of all men aged 45 to 59 years living in Caerphilly, South
Wales. From the 2512 men taking part in the main study ( $90 \%$ response rate) a systematic 3 in 10 sample was selected, and these men were asked to complete a seven-day weighed dietary record. This report presents data from the first 387 men; data from a further nine men were excluded for incomplete or doubtful records. Response rate for this part of the study was also $90 \%$.

Men were invited to an evening clinic, where examination included height determination by Holtain stadiometer and weight (in light clothing) on a beam balance. At the end of the clinic visit, one "casual" supine reading of blood pressure was measured by a single observer. Diastolic blood pressure was taken at the disappearance of the Korotkoff sounds (phase V); blood pressure values were not corrected for ambient temperature. Men taking antihypertensive therapy were identified from drug history on a questionnaire.

Some three to six weeks after the clinic visit, participants were seen at home and asked to complete a weighed inventory of all food and drink consumed over seven days. Details of the survey method have been published elsewhere. ${ }^{20}{ }^{21}$ Briefly, all individual items of food and drink were weighed and recorded, including any "left overs". The men were visited at home the day before the record was to begin, and the 
method was explained. Further visits took place the following day to ensure that the method had been understood, and again the day after completion of the record. Other visits were made as necessary. The records were thoroughly checked to ensure that all the required information had been recorded. If meals were taken outside the home they were described, and quantities were estimated in household measures. Nutrient, fibre, and energy intakes were calculated using computerised food composition tables ${ }^{22}$ with data for some additional foods. ${ }^{23}$ Household recipes were used if these differed from recipes in the food tables.

Alcohol consumption was estimated both from a questionnaire and from weighed dietary records. Questionnaire data, which in general yielded higher values of alcohol consumption, ${ }^{24}$ were used in this report. Consumption was converted into millilitres of ethyl alcohol per week using data provided by the manufacturers.

\section{Statistical methods}

Data were analysed using the Statistical Analysis System. ${ }^{25}$ The body mass index (BMI) was used as a measure of adiposity and was calculated as weight (kg)/height ${ }^{2}\left(\mathrm{~m}^{2}\right)$.

The following variables were considered in the analysis, and their relations to blood pressure were explored by simple, multiple, and logistic regression: BMI, alcohol consumption, cigarette smoking, social class, exercise, polyunsaturated to saturated fat $(\mathbf{P} / \mathbf{S})$ ratio, \% energy as fat, and the intakes of energy, protein, carbohydrates, potassium, calcium, cereal, and total dietary fibre, fats, and saturated, monounsaturated, and polyunsaturated fatty acids. To take some account of differences in total food consumption, analyses were also performed replacing potassium and calcium intakes by their ratios to energy intake $(\mathrm{mg} / 1000 \mathrm{kcal})$.

Owing to the problems in estimating the sodium content of foods and that added in the cooking and at the table, ${ }^{26}$ sodium intake was not considered in this study.

Alcohol intake was treated as both a continuous variable and a discrete variable classified into four groups: nil, light ( $<100 \mathrm{ml}$ of ethyl alcohol per week), light to moderate $(100-299 \mathrm{ml}$ per week), and moderate to heavy ( $\geq 300 \mathrm{ml}$ per week). The Office of Population Censuses and Surveys ${ }^{27}$ defines 1 "unit" (drink) of alcohol as the equivalent of half a pint of beer, a single measure of spirits, a glass of wine, or a small glass of fortified wine. Each drink contains approximately 10 to $13 \mathrm{ml}$ of ethyl alcohol, so that our highest category corresponded to about 4 units of alcohol per day. For analyses involving alcohol as a continuous variable, data were excluded for two men with outlying values of alcohol intake $(3350 \mathrm{ml}$ and $4423 \mathrm{ml}$ ethyl alcohol per week).

Cigarette smoking was classified into three groups: current cigarette smoker, ex-smoker, and lifelong non-smoker. Data for 38 cigar and pipe smokers were excluded from these analyses. "Exercise" was classified into two groups ("high" and "low"), based on questionnaire data concerning physical activity at work and in leisure time. Specifically, men were placed in the "high" exercise group if they answered "yes" to each of the following three questions:

"When you are doing your work are you normally physically active?"

"During the past seven days have you done any heavy work or taken any exercise in your leisure time?", and "Is this activity a regular habit?"

Social class was coded by present or most recent occupation according to the Registrar General's Classification. ${ }^{28}$

For the multiple regression analyses, either systolic blood pressure (SBP) or diastolic blood pressure (DBP) was entered as the dependent variable, age being treated as a 'control' variable. All other variables were considered as independent or 'explanatory' variables. The data were also explored by logistic regression.

\section{Results}

There was evidence that relations of diet to blood pressure differed for the 356 men not on antihypertensive therapy and the 31 men on treatment. They were therefore considered separately in the analysis.

MEN NOT ON ANTIHYPERTENSIVE THERAPY Mean age was 51.5 years, mean blood pressure was $140.7 / 90.4 \mathrm{mmHg}$ (SD 18.7/11.7), and mean BMI was 25.9 (SD 3.0). There was a positive gradient of blood pressure with age, which was significant for SBP $(p<0.001)$ but non-significant for DBP. Dietary intakes tended to decline with age; these trends were significant for energy $(p<0.05)$ and potassium $(\mathrm{p}<0.001)$. Age-adjusted means of the dietary variables by blood pressure and treatment categories are shown in table 1.

\section{ENERGY, FIBRE, AND NUTRIENTS}

A wide range of intakes was apparent. For example, the weekly intake of fat ranged from $187 \mathrm{~g}$ to $1621 \mathrm{~g}$ (mean $695 \mathrm{~g}$, SD 199); of dietary fibre from $37 \mathrm{~g}$ to $286 \mathrm{~g}$ (mean 133g, SD 47); of potassium from $7703 \mathrm{mg}$ to స్ట $52767 \mathrm{mg}$ (mean 21798 , SD 5432), and of calcium from $1627 \mathrm{mg}$ to $13550 \mathrm{mg}$ (mean 6122, SD 1902). Fat intake accounted for $37.5 \%$ (SD 5.8) of energy on 
Table 1 Age-adjusted average weekly consumption of energy, alcohol, fibre and nutrients by blood pressure and treatment category

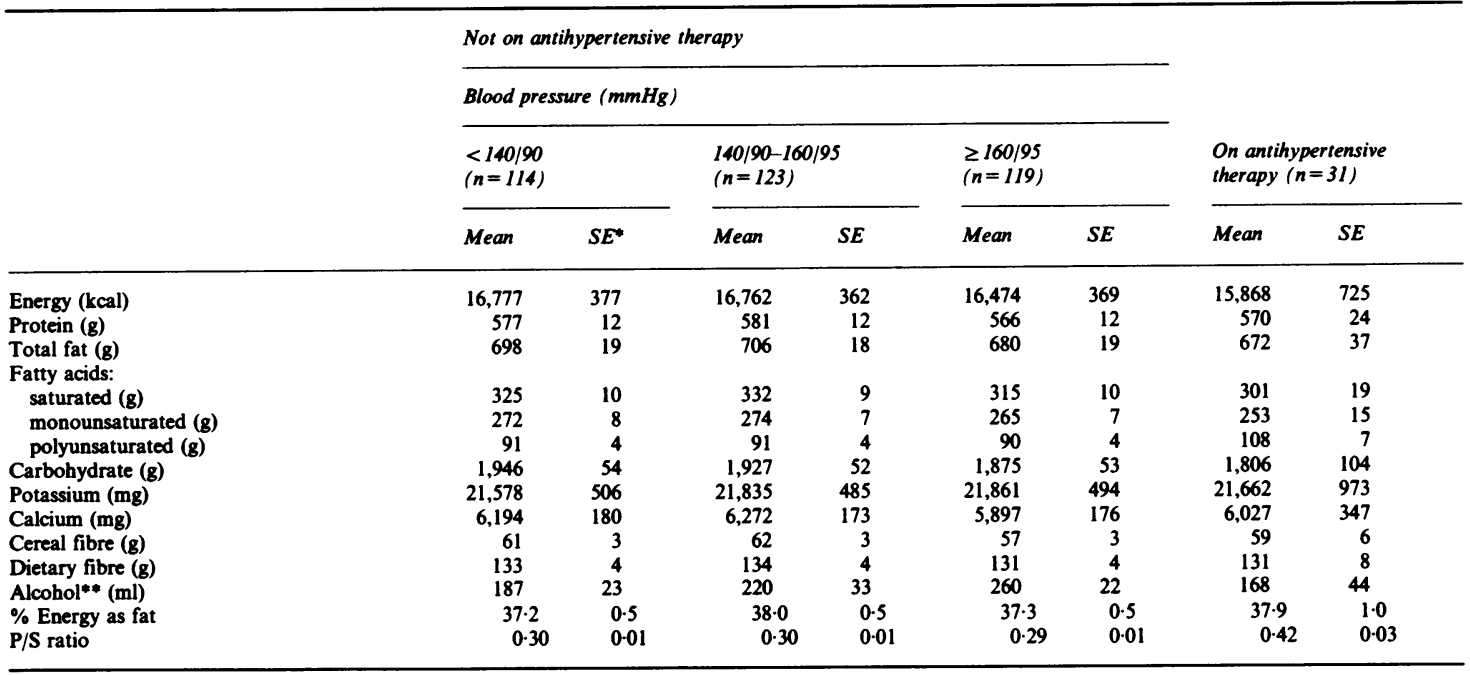

- Standard error

** Alcohol intake estimated in ml ethyl alcohol per week. Data for drinkers only as follows: $<140 / 90$ (103); 140/90-160/95 (120); $\geq 160 / 95$ (111); on treatment (29).

There were 18 abstainers. Drinking status unknown for six men.

average and at least $40 \%$ of energy for 121 men (34\%). Fat was mainly saturated with a mean $\mathrm{P} / \mathrm{S}$ ratio of $0 \cdot 30$ (SD 0.15).

There was a tendency for lower intakes of energy, protein, fat, fatty acids, carbohydrates, and fibre in men with the higher blood pressures (table 1) but the differences were small and none of the regression slopes of blood pressure on dietary variables was significant. For example, simple regression estimates indicated that an increase in energy of $1000 \mathrm{kcal}$ per week, in protein of $25 \mathrm{~g}$ per week, or in cereal fibre of $5 \mathrm{~g}$ per week was associated with a fall in SBP of only $0.1 \mathrm{mmHg}(95 \%$ confidence intervals $(\mathrm{CI})$ for the change in SBP were $-0.6 \mathrm{mmHg}$ to $+0.4 \mathrm{mmHg}$, $-0.5 \mathrm{mmHg}$ to $+0.3 \mathrm{mmHg}$, and $-0.4 \mathrm{mmHg}$ to $+0.2 \mathrm{mmHg}$ respectively).

No consistent or significant relations were apparent between blood presssure and the intakes of either calcium or potassium. Thus an increase in weekly calcium intake of $1000 \mathrm{mg}$ was associated with a fall in SBP of $0.2 \mathrm{mmHg}(95 \% \quad \mathrm{CI}-1.2 \mathrm{mmHg}$ to $+0.8 \mathrm{mmHg})$ but a rise in DBP of $0.1 \mathrm{mmHg}(95 \% \mathrm{CI}$ $-0.6 \mathrm{mmHg}$ to $+0.7 \mathrm{mmHg}$ ). Similarly, an increase in weekly potassium intake of $1000 \mathrm{mg}$ was associated with a fall in SBP of $0.1 \mathrm{mmHg}(95 \% \mathrm{CI}-0.4 \mathrm{mmHg}$ to $+0.3 \mathrm{mmHg})$ and a rise in DBP of $0.1 \mathrm{mmHg}(95 \%$ $\mathrm{CI}-0.1 \mathrm{mmHg}$ to $+0.3 \mathrm{mmHg}$ ). The potassium to energy ratio was, however, positively and significantly correlated with DBP $(r=0 \cdot 10, p<0 \cdot 05)$.
EXERCISE, SMOKING AND SOCIAL CLASS

No consistent relation of exercise to blood pressure was observed.

Blood pressures were higher in lifelong nonsmokers than in current cigarette smokers (141.5/ $92.9 \mathrm{mmHg}$, SE $2.2 / 1.7 v 139.5 / 89.2 \mathrm{mmHg}$, SE $1 \cdot 4 / 0 \cdot 8)$, the difference being significant for DBP $(p<0.05)$. Ex-smokers had intermediate pressures. Average blood pressures were also higher in social classes IV and V than in I and II, but these differences were not significant. Non-smokers, men in social classes IV and V, and the "low" exercise group tended to be more obese than their counterparts.

\section{OBESITY AND ALCOHOL}

The relations of BMI and alcohol to blood pressure are shown in table 2. BMI and alcohol consumption weresignificantly related to both $\operatorname{SBP}(r=0 \cdot 14, p<0.01$; and $r=0.13, p<0.05$ respectively) and DBP $(r=0.18$, $\mathrm{p}<0.001 ;$ and $\mathrm{r}=0.16, \mathrm{p}<0.01$ respectively), and these effects were largely additive (table 2 ).

MULTIPLE AND LOGISTIC REGRESSION Many of the variables considered above were interdependent. For example, only $7 \%$ of the "moderate to heavy" alcohol group were lifelong non-smokers compared with $25 \%$ of the "nil to light" group $(p<0.001)$. To take account of these effects, the data were further explored by multiple regression. 
Table 2 Age adjusted mean blood pressure by alcohol intake and body mass index excluding men on treatment (A further 8 men were excluded because of missing values)

\begin{tabular}{|c|c|c|c|c|c|c|c|c|}
\hline \multirow[b]{2}{*}{ Alcohol ( $\mathrm{ml} / w k)$} & \multicolumn{8}{|c|}{ Body mass index $\left(\mathrm{kg} / \mathrm{m}^{2}\right)$} \\
\hline & $n$ & $\begin{array}{l}<24 \\
B P(S E)^{*}\end{array}$ & $n$ & $\begin{array}{l}24-26.99 \\
B P(S E)\end{array}$ & $n$ & $\begin{array}{l}\geqslant 27 \\
B P(S E)\end{array}$ & $n$ & $\begin{array}{l}\text { Total } \\
B P(S E)\end{array}$ \\
\hline \multicolumn{9}{|l|}{ (a) Systolic BP } \\
\hline $\mathrm{Nil}$ & 5 & $\begin{array}{r}128 \cdot 4 \\
(8 \cdot 1)\end{array}$ & 4 & $\begin{array}{r}126 \cdot 1 \\
(9 \cdot 0)\end{array}$ & 7 & $\begin{array}{r}142.5 \\
(6 \cdot 8)\end{array}$ & 16 & $\begin{array}{r}132 \cdot 3 \\
(4 \cdot 6)\end{array}$ \\
\hline$<100$ & 40 & $\begin{array}{r}136.6 \\
(2.9)\end{array}$ & 58 & $\begin{array}{r}139 \cdot 6 \\
(2 \cdot 4)\end{array}$ & 50 & $\begin{array}{r}141 \cdot 4 \\
(2 \cdot 6)\end{array}$ & 148 & $\begin{array}{r}139 \cdot 2 \\
(1 \cdot 5)\end{array}$ \\
\hline $100-299$ & 32 & $\begin{array}{r}140 \cdot 9 \\
(3 \cdot 2)\end{array}$ & 46 & $\begin{array}{r}140 \cdot 6 \\
(2 \cdot 7)\end{array}$ & 36 & $\begin{array}{r}140 \cdot 4 \\
(3 \cdot 0)\end{array}$ & 114 & $\begin{array}{r}140 \cdot 6 \\
(1 \cdot 7)\end{array}$ \\
\hline$\geqslant 300$ & 17 & $\begin{array}{r}137 \cdot 5 \\
(4 \cdot 4)\end{array}$ & 32 & $\begin{array}{r}144 \cdot 3 \\
(3 \cdot 2)\end{array}$ & 21 & $\begin{array}{r}154 \cdot 7 \\
(3.9)\end{array}$ & 70 & $\begin{array}{r}145 \cdot 5 \\
(2 \cdot 2)\end{array}$ \\
\hline Total & 94 & $\begin{array}{r}135.9 \\
(2.5)\end{array}$ & 140 & $\begin{array}{r}137.6 \\
(2.6)\end{array}$ & 114 & $\begin{array}{r}144 \cdot 8 \\
(2 \cdot 2)\end{array}$ & 348 & 140.8 \\
\hline \multicolumn{9}{|l|}{ (b) Diastolic BP } \\
\hline Nil & 5 & $\begin{array}{l}80 \cdot 3 \\
(5 \cdot 1)\end{array}$ & 4 & $\begin{array}{l}83 \cdot 9 \\
(5 \cdot 7)\end{array}$ & 7 & $\begin{array}{l}99 \cdot 5 \\
(4 \cdot 3)\end{array}$ & 16 & $\begin{array}{l}87.9 \\
(2.9)\end{array}$ \\
\hline$<100$ & 40 & $\begin{array}{l}85.7 \\
(1.8)\end{array}$ & 58 & $\begin{array}{l}91 \cdot 0 \\
(1 \cdot 5)\end{array}$ & 50 & $\begin{array}{l}89 \cdot 2 \\
(1 \cdot 6)\end{array}$ & 148 & $\begin{array}{l}88.6 \\
(0.9)\end{array}$ \\
\hline $100-299$ & 32 & $\begin{array}{l}87 \cdot 6 \\
(2 \cdot 0)\end{array}$ & 46 & $\begin{array}{l}90 \cdot 2 \\
(1 \cdot 7)\end{array}$ & 36 & $\begin{array}{l}92 \cdot 3 \\
(1 \cdot 9)\end{array}$ & 114 & $\begin{array}{c}90.00 \\
(1.1)\end{array}$ \\
\hline$\geqslant 300$ & 17 & $\begin{array}{l}89.9 \\
(2.8)\end{array}$ & 32 & $\begin{array}{l}94 \cdot 2 \\
(2 \cdot 0)\end{array}$ & 21 & $\begin{array}{l}96 \cdot 0 \\
(2 \cdot 5)\end{array}$ & 70 & 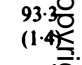 \\
\hline Total & 94 & $\begin{array}{l}85.9 \\
(1.6)\end{array}$ & 140 & $\begin{array}{l}89 \cdot 8 \\
(1.6)\end{array}$ & 114 & $\begin{array}{l}94 \cdot 2 \\
(1 \cdot 4)\end{array}$ & 348 & 90.3라 \\
\hline
\end{tabular}

* $\mathrm{SE}=$ Standard error

Initially BMI, alcohol intake, smoking, exercise, and social class were considered together as independent variables (with age as a control variable). These variables and possible interactions were retained only if the F-ratio was significant at the 5\% level, having accounted for other variables in the model. Each dietary variable was then added in turn to the models for SBP and DBP and retained if significant at the 5\% level.

The results generally confirmed those observed on univariate analyses and are shown in table 3. Age, BMI, and alcohol were significantly related to SBP, and BMI and alcohol to DBP. Possible interactions, and a quadratic term for alcohol, were not significant nor were the terms for social class and exercise. Smoking was of borderline significance in the model for DBP $(p=0.06)$.

When the dietary variables were added to these models, none was found to be significantly related to blood pressure. In particular, the positive correlation of DBP with the potassium to energy ratio was no longer evident. The proportions of total variance explained by the 'optimal' models shown in table 3 were $\mathbf{7 . 7 \%}$ for SBP and $\mathbf{6} \cdot 1 \%$ for DBP.

For the logistic regression analyses, two $\bar{\partial}$ dichotomous $(0,1)$ variables were created: 'raised blood pressure' (defined as SBP $\geq 140 \mathrm{mmHg}$ and/or DBP $\geq 90 \mathrm{mmHg}$ ) and 'hypertension' (defined as SBP $\geq 160 \mathrm{mmHg}$ and/or DBP $\geq 95 \mathrm{mmHg}$ ). By these criteria, 242 men (68\%) had raised blood pressure, and 119 men $(33 \%)$ were hypertensive. None of the variables was significantly predictive of raised blood pressure, but when hypertension was considered as the dependent variable, results similar to the multiple $₹$ regression analyses were observed. Age $(p<0.05)$, BMI $(p<0.05)$, and alcohol $(p<0.01)$ were positive predictors of hypertension. The regression coefficient for alcohol indicated that men consuming $300 \mathrm{ml}$ pure alcohol per week were at a 1.6 risk of being $N$ hypertensive compared with non-drinkers $(95 \%$ N confidence interval $1 \cdot 2$ to $2 \cdot 1$ ). When dietary variables $\underset{\mathrm{E}}{ }$ were added to the model, protein intake was also found to be related to hypertension, but inversely $(\mathrm{p}<0.05)$. 
Table 3 Multiple regression models, excluding men on treatment

(A further 10 men were excluded for missing or extreme values)

\begin{tabular}{lll}
\hline (a) Dependent variable: & \multicolumn{2}{l}{ Systolic blood pressure } \\
\cline { 2 - 3 } & Slope B & $S E(B)$ \\
\hline Intercept & 73.5 & \\
Age & $0.86^{* * *}$ & 0.22 \\
BMI & $0.80^{*}$ & 0.32 \\
Alcohol & $0.011^{* *}$ & 0.004 \\
Multiple $\mathrm{R}^{2}=0.077$ & & \\
\hline
\end{tabular}

\begin{tabular}{lll}
\hline (b) Dependent variable: & \multicolumn{2}{l}{ Diastolic blood pressure } \\
\cline { 2 - 3 } & Slope B & $S E(B)$ \\
\hline Intercept & $64 \cdot 8$ & \\
Age & 0.12 & 0.14 \\
BMI & $0.70^{* * *}$ & 0.20 \\
Alcohol & $0.008^{* *}$ & 0.002 \\
Multiple $\mathrm{R}^{2}=0.061$ & & \\
\hline
\end{tabular}

$\begin{array}{rl}p & p 0.05 \\ \mathrm{p}<0.01 & 0.01\end{array}$

*.* $p<0.001$

\section{MEN ON ANTIHYPERTENSIVE THERAPY}

Mean $\mathbf{P} / \mathrm{S}$ ratio was significantly higher for the men on treatment compared with the other men $(p<0.01)$, but other differences were not significant (table 1). For the treated men, there were statistically significant associations between DBP and a number of dietary variables. DBP was inversely related to the intakes of energy $(r=-0.43, p<0.05)$, protein $(r=-0.42$, $\mathrm{p}<0.05)$, carbohydrate $(\mathrm{r}=-0.43, \mathrm{p}<0.05)$, polyunsaturated fat $(r=-0.46, p<0.01)$, cereal fibre $(r=-0.46, p<0.01)$, total dietary fibre $(r=-0.58$, $\mathrm{p}<0.001)$, potassium $(\mathrm{r}=-0.48, \mathrm{p}<0.01)$, and calcium $(r=-0.43, p<0.05)$. SBP was also inversely related to these variables, but not significantly.

To investigate whether these associations may have been related to changes in diet, response to the question, "Are you on any special diet?" was analysed. Altogether $35 \%$ (11 men) admitted to being on a special diet: 6 were on a slimming diet, 1 on a diabetic diet, and 4 on "other medical diets" including "low cholesterol" (1), "low fat" (1), "no fat" (1) and "no animal fat" (1). By contrast, only $8 \%$ (30 men) of the men not on antihypertensive therapy admitted to a special diet $(\mathrm{p}<0.001)$.

\section{Discussion}

Mortality rates for men in Wales for hypertension, stroke, and ischaemic heart disease are high compared with rates for England and Wales combined (standardised mortality ratios of 141, 110, and 112 respectively $^{29}$ ). Recent reports setting out nutritional guidelines for Great Britain have stressed the importance of diet in the prevention of cardiovascular disease. ${ }^{3031}$ Overall, men in this study could be considered 'unhealthy' with respect to their diets and other risk factors. In common with Britain as a whole, diets were high in fat, particularly saturated fat, and low in fibre. Forty-seven per cent were smokers, alcohol consumption was higher than in some other regions of England and Wales, ${ }^{27}$ and the men were generally more overweight than has been recorded in other surveys. ${ }^{32}$ In addition, average blood pressures were high, and there was a high prevalence of hypertension.

For men not on treatment, only a small proportion of the total variance in blood pressure could be 'explained' by the variables measured in this study, and there was little evidence for a relation between diet and blood pressure. Although an association with blood pressure was observed for the potassium to energy ratio, this was not consistent and was in a direction opposite to that expected. ${ }^{1011}$ However, the observation of lower protein intake in men with hypertension is consistent with recent experimental evidence of a blood pressure lowering effect of dietary proteins. $^{33}$

We were unable to confirm previous epidemiological observations of inverse relations between blood pressure and the intakes of potassium ${ }^{11}$ and calcium or milk products. ${ }^{1618}$ Previous studies relied on 24-hour dietary recall, which is more liable to bias, error, and misclassification than the seven-day weighed dietary inventory method, ${ }^{19}$ and in general the associations reported in these studies were weak. ${ }^{111618}$ Nevertheless, the possibility of false negative results in our own study should be considered. Firstly, the data were cross-sectional and related current blood pressure to current dietary intake, although determinants of blood pressure may be cumulative and start early in life. ${ }^{34}$ Secondly, intraindividual variations in blood pressure ${ }^{35}$ and $\operatorname{diet}^{36}$ result in misclassification of individuals, with the effect that true correlations are biased downwards towards zero. (Similar arguments have been put forward to explain the lack of correlation within populations between salt excretion and blood pressure, ${ }^{37}$ and between fat intake and levels of serum cholesterol. ${ }^{38}$ ) Finally, the power of the study to detect significant effects of diet on blood pressure may have been limited in this relatively homogeneous population.

Among men on treatment, significant correlations between dietary variables and blood pressure were observed. These men appear to have modified their diets, increasing the mean $P / S$ ratio, and 11 admitted to being on a "special" diet, including four who had 
deliberately reduced the fat or cholesterol contents of their diets. How might these changes explain the associations observed between diet and blood pressure? The most likely possibility is that men changing their diets were more "health conscious" and as a result more likely to comply with their antihypertensive therapy. Alternatively, changes in diet by some individuals, possibly in combination with drug treatment, may have brought about falls in blood pressure.

Evidence from clinical trials lends some support to this view. We know, for example, that short-term administration of potassium ${ }^{10}$ or an increase in the $P / S$ ratio $^{13}$ can lower blood pressure in man. There is also evidence from trials of salt restriction for hypertension ${ }^{39} 40$ that change of diet can result in increased drug-mediated falls in blood pressure. If one or both of these mechanisms were operating, it would not be possible from these cross-sectional data to determine which dietary variable was primarily responsible (although on multiple regression, dietary fibre contributed most to the variance of blood pressure).

The association of raised blood pressure and adiposity is well known, but relations between alcohol intake and blood pressure are less well defined. In the Kaiser Permanente Study, Klatsky et al observed a threshold effect of alcohol on blood pressure at an intake of about three drinks per day. ${ }^{4}$ Subsequent reports have tended either to confirm the existence of a threshold effect $^{56}$ or to show a linear relation between alcohol and blood pressure. ${ }^{78}$

In defining the alcohol-blood pressure relation, it is important to take adequate account of confounding. In this study, we were able to allow for the effects of dietary variables, as well as age, adiposity, social class, exercise, and smoking habits. Our results suggest a modest linear effect of alcohol on SBP with an increase in SBP of about $0.9 \mathrm{mmHg}$ for each alcoholic drink consumed a day. For DBP, confidence intervals were wide, so that a "threshold" effect (at about $300 \mathrm{ml}$ per week) could not be excluded. Overweight men who consumed at least four drinks a day were at particular risk of hypertension (table 2).

In summary, we found little evidence for a relation between diet and blood pressure, although it is possible that diet change may have contributed to falls in blood pressure in men on antihypertensive therapy. To aid in the interpretation of diet-blood pressure relations we recommend that questions on recent dietary change be included in future studies. Adiposity and moderate alcohol intake were risk factors for hypertension, and we would agree with others ${ }^{9}$ that an alcohol interview should form part of the assessment of the hypertensive patient. Both weight $\operatorname{loss}^{41}$ and sustained abstention from alcohol ${ }^{42}$ are associated with falls in blood pressure, and it seems appropriate that primary prevention of hypertension should include measures to reduce the prevalence of obesity, and to moderate the use of alcohol.

Dr P Elliott is supported by a grant from the Wellcome Trust, London. This work formed part of a thesis submitted by Dr Elliott towards an MSc degree in epidemiology, University of London.

Correspondence and reprint requests to Dr P Elliott, St Mary's Hospital Medical School, Norfolk Place, London W2

\section{References}

${ }^{1}$ Dawber TR. The Framingham Study. Cambridge, Mass and London: Harvard University Press, 1980 91-120

2 Stamler J, Farinaro E, Mojonnier LM, Hall Y, Moss D, Stamler R. Prevention and control of hypertension by nutritional-hygienic means. Long-term experience of the Chicago coronary prevention evaluation program.JAMA 1980; 243: 1819-23.

${ }^{3}$ Simpson FO. Salt and hypertension: a sceptical review the evidence. Clin Sci 1979; 57: 463s-80s.

${ }^{4}$ Klatsky AL, Friedman GD, Siegelaub AB, Gerard MP Alcohol consumption and blood pressure. New Engl 7 Med 1977; 296: 1194-200.

${ }^{5}$ Criqui MH, Wallace RB, Mishkel M, Barret-Connor Heiss G. Alcohol consumption and blood pressure. The Lipid Research Clinics Prevalence Study. Hypertension 1981; 3: 557-65.

${ }^{6}$ Cairns V, Keil U, Kleinbaum D, Doering A, Stieber J. Alcohol consumption as a risk factor for high blood pressure. Munich Blood Pressure Study. Hypertension 1984; 6: 124-31.

${ }^{7}$ Cooke KM, Frost GW, Thornell IR, Stokes GS. Alcohol consumption and blood pressure. Survey of the relationship at a health-screening clinic. Med J Aust 1982; 1: 65-9.

${ }^{8}$ Saudie E, Grosslight GM, Adena MA. Relation of alcohol and cigarette consumption to blood pressure and serum creatinine levels. J Chron Dis 1984; 37: 617-23.

${ }^{9}$ Fortmann SP, Haskell WL, Vranizan K, Brown BW, Farquhar JW. The association of blood pressure and dietary alcohol: differences by age, sex, and estrogen use. Am J Epidemiol 1983; 118: 497-507.

${ }^{10}$ MacGregor GA, Smith SJ, Markandu ND. Moderate potassium supplementation in essential hypertension. Lancet 1982; ii: 567-70.

11 Khaw K-T, Barret-Connor E. Dietary potassium and $D$ blood pressure in a population. Am J Clin Nutr 1984; 39: 963-8.

12 Wright A, Burstyn PG, Gibney MJ. Dietary fibre and $N$ blood pressure. $\mathrm{Br}$ Med J 1979; 2: 1541-3.

13 Puska P, Iacono JM, Nissinen A, et al. Controlled, N randomised trial of the effect of dietary fat on blood $N$ pressure. Lancet 1983; i: 1-5.

14 Rouse IL, Beilin LJ, Armstrong BK, Vardongen R. Blood pressure lowering effect of a vegetarian diet: controlled $\varrho$ trial in normotensive subjects. Lancet 1983; i: 5-10. 
${ }^{15}$ Kesteloot H, Geboers J, Van Hoof R. Epidemiological study of the relationship between calcium and blood pressure. Hypertension 1983; 5: (Suppl II): II-52 - II-56.

16 Ackley S, Barret-Connor E, Suarez L. Dairy products, calcium, and blood pressure. Am J Clin Nutr 1983; 38; 457-61.

${ }^{17}$ Harlan WR, Hull AL, Schmouder RL, Landis R, Thompson FE, Larkin FA. Blood pressure and nutrition in adults. The National Health and Nutrition Examination Survey. Am J Epidemiol 1984; 120: 17-28.

${ }^{18}$ Garcia-Palmieri MR, Costas R, Cruz-Vidal M, Sorlie PD, Tillotson J, Havlik RJ. Milk consumption, calcium intake, and decreased hypertension in Peurto Rico. Hypertension 1984; 6: 322-8.

${ }^{19}$ Marr JW. Individual dietary surveys: purposes and methods. World Rev Nutr Diet 1971; 13: 105-64.

${ }^{20}$ Fehily AM, Milbank JE, Yarnell JWG, Hayes TM, Kubiki AJ, Eastham RD. Dietary determinants of lipoproteins, total cholesterol, viscosity, fibrinogen and blood pressure. Am J Clin Nutr 1982; 36; 890-6.

${ }^{21}$ Fehily AM, Phillips KM, Sweetnam PM. A weighed dietary survey of men in Caerphilly, South Wales. Hum Nutr: Appl Nutr 1984; 384: 270-6.

22 Paul AA, Southgate DAT. McCance and Widdowson's the composition of foods. 4th edition London: HMSO, 1978.

23 Wiles SJ, Nettleton PA, Black AE, Paul AA. The nutrient composition of some cooked dishes eaten in Britain: a supplementary food composition table. J Hum Nutr 1980; 34: 189-224.

24 Yarnell JWG, Fehily AM, Milbank JE, Sweetnam PM, Walker CL. A short dietary questionnaire for use in an epidemiological survey: comparison with weighed dietary records. Hum Nutr; Appl Nutr 1983; 37A; 103-12.

${ }^{25}$ SAS User's Guide. 1982 Edition. SAS Institute Inc, Box 8000, Cary, North Carolina 27511.

${ }^{26}$ Bender AE. Sodium content of foods. Lancet 1977; ii: 249.

27 Wilson P. Drinking in England and Wales. London: HMSO, 1980.

28 Office of Population Censuses and Surveys. Classification of occupations. London: HMSO, 1980.

${ }^{29}$ Office of Population Censuses and Surveys. Mortality statistics. Area. 1983. London: HMSO, 1984.
${ }^{30}$ Health Education Council. A discussion paper on proposals for nutritional guidelines for health education in Britain. Prepared for the National Advisory Committee on Nutrition and Education by an ad hoc working party under the chairmanship of Professor WPT James. London: Health Education Council, 1983.

31 Committee on Medical Aspects of Food Policy. Diet and Cardiovascular disease. Report on Health and Social Subjects 28. London: HMSO, 1984.

32 Report of the DHSS/MRC Group. Research on obesity. London: HMSO, 1976.

${ }^{33}$ Yamori $Y$, Horie R, Nara Y, et al. Dietary prevention of hypertension in animal models and its applicability to human. Ann Clin Res 1984; 16 (Suppl. 43): 28-31.

${ }^{34}$ Hofman A, Valkenburg HA. Determinants of change in blood pressure during childhood. Am J Epidemiol 1983; 117: $735-43$.

${ }^{35}$ Armitage P, Fox W, Rose GA. The variability of measurements of casual blood pressure-II-Survey experience. Clin Sci 1966; 30: 337-44.

${ }^{36}$ Marr JW. Individual variation in dietary intake. In: Preventive nutrition in society. Ed: Turner MR. London, New York: Academic Press, 1983.

${ }^{37}$ Liu K, Cooper R, McKeever J, et al. Assessment of the association between habitual salt intake and high blood pressure: methodological problems. Am J Epidemiol 1979; 110: 219-26.

38 Jacobs DR, Anderson JT, Blackburn H. Diet and serum cholesterol. Do zero correlations negate the relationship? Am J Epidemiol 1979; 110: 77-87.

39 Parijs J, Joossens JV, Van der Linden L, et al. Moderate sodium restriction and diuretics in the treatment of hypertension. Am Heart J 1973; 85: 22-34.

40 Beard TC, Cooke HM, Gray WR, Barge R. Randomised controlled trial of a no-added-sodium diet for mild hypertension. Lancet 1982; ii: 455-8.

${ }^{41}$ Reisin E, Abel R, Modan M, Silverberg DS, Eliahou HE, Modan B. Effect of weight loss without salt restriction on the reduction of blood pressure in overweight hypertensive patients. New Engl J Med 1978; 298: 1-6.

${ }^{42}$ Saunders JB, Beevers DG, Paton A. Alcohol-induced hypertension. Lancet 1981; ii: 653-6. 